\title{
Acute toxic effects on hematological and histological features in adult frogs, Rana tigrina exposed to lambda-cyhalothrin pesticide
}

\author{
Aamna Nazar ${ }^{1,2}$, Razia Iqbal ${ }^{1 *}$, Muhammad Rizwan ${ }^{3}$, Muhammad Zeeshan Nazar \\ ${ }^{I}$ Department of Zoology, University of Gujrat, Gujrat-50700, Pakistan \\ ${ }^{2}$ Department of Zoology, GC University Faisalabad, Sub-Campus Layyah-31200, Pakistan \\ ${ }^{3}$ Department of Botany, GC University Faisalabad, Sub-Campus Layyah-31200, Pakistan \\ ${ }^{4}$ Department of Agriculture Entomology, Faculty of Agriculture Sciences and Technology, Bahauddin Zakariya \\ University, 60800-Multan, Pakistan \\ Corresponding Author's Email: razia.iqbal@uog.edu.pk
}

\begin{abstract}
The unwise use of pesticides has placed the amphibians at high risk in agricultural landscapes. Adverse effects of insecticides on the aquatic life of amphibians such as fecundity rate, complete blood count (CBC), and liver function test (LFT) need to address conspicuously. The current investigation reports the effects of Lambda-Cyhalothrin (LCT), a widely used pyrethroids type-II, on histological and hematological features of frogs (Rana tigrina), collected from a paddy field, in agricultural overspray setting. The results showed that high degeneration in frog's gonads and extensive deviation in CBC, LFT, and reproductive hormones values, suggested the prescribed dosage of currently registered products. The effects of LCT on frogs were effectively performed by microtomy on gonads and statistical analysis on blood profile. The statistical analysis results in the average response (P-value $>0.05)$ of all applied doses (8 ppb, $10 \mathrm{ppb}$, and $12 \mathrm{ppb})$, alarm the toxic nature of LCT for amphibians and their decline, demands more attention in preservation efforts.
\end{abstract}

Keywords: Insecticides; Histology; Amphibians; Pyrethroids; Microtomy.

\section{Highlights}

$>$ Monitoring the adverse effects of pesticide Lambda-Cyhalothrin (LCT) on frogs (Rana tigrina).

$>$ Histological and hematological features of frogs altered destructively by LCT inputs.

$>$ High degeneration in frog's gonads and reproductive hormones are observed.

$>$ Statistical analysis on blood profile accomplished magnificently.

$>$ Even a sub-lethal dose affected the amphibians' survival in the ecosystem.

\section{Introduction}

The global decline in amphibians from ecosystems came to the world's consideration since the last couple of decades and was exclusively discussed (Blaustein et al., 1994; Fisher and Shaffer, 1996; Grant et al., 2019; Li et al., 2014; Pechmann et al., 1991; Pechmann and Wilbur, 1994; Wake, 1998). Amphibians are a substantial part of the food chain and are used as bio-indicators of environmental contamination due to their vulnerability to chemicals at some stage in the water cycle (Grant et al., 2019). Toxicological study on amphibians has been relatively limited in contrast to the other vertebrates (Kumari and Sinha, 2009). The noticeable contributing features to amphibian's decline are environmental pollution and change in the climate (Alford and Richards, 1999; Chen et al., 2018). Direct contact with various pesticides spray is extremely fatal to amphibians (Relyea, 2005). Pesticides are harshly influenced on the amphibians in diverse ways (Majewski and Capel, 1996), like, kill amphibians directly, affect their activities, lessen their development rates, act as endocrine disrupters or stimulate immune-suppression (Alford and Richards, 1999; Bishop, 1992; Carey and Bryant, 1995).

Pyrethroids are synthetic analogs of pyrethrins, insecticidal substances obtained from the flowers of a species of chrysanthemum (Chrysanthemum cinerariaefolium) and an essential means in community fitness to manage household pests i.e., cockroaches, mosquitoes, ticks, and flies, which are executed as infection vectors (Ecobichon, 1991; He et al., 2008). These insecticides are ubiquitous in the aquatic environment via runoff from sprayed fields, lawns, parking lots, etc., during rainstorm events, and, to a lesser extent through spray drift where it is toxic to non-target aquatic invertebrates as well vertebrates such as fish and amphibians (Ali et al., 2011; Fishel, 2005; Lu et al., 2019). The predictable symptoms reported in 
the literature are that when amphibians were exposed to sub-lethal concentrations to pyrethroids include; in-coordination, lack of limb control, hyperactivity, and early amphibian development, voltage-dependent neuromuscular sodium channels causing convulsions, hyper-excitation, and tremors (Greulich and Pflugmacher, 2003; Right and van den Bercken, 1986; Van Den Bercken, 1977; Vijverberg et al., 1982).

Specifically, Lambda-Cyhalothrin (LCT), a class of pyrethroids, penetrates to the organism's cuticle, having knockdown action by disrupting the nerve transmission within a minute; this directs to termination of nourishing, loss of muscular control, paralysis, and ultimately the death of the organism (He et al., 2008). It also affects the organs (liver, kidney, and gonads), blood, serum biochemical as well as tissue pathological changes of toads (Bufo perreti) and can also change their level of excretory products (Davidson et al., 2001; Davidson et al., 2002; Lawrence and Isioma, 2010; Lenkowski et al., 2010). LCT is a widely used insecticide to control pests in agriculture, public health, home, and garden (Amweg et al., 2005). Despite its valuable functions, it can be toxic for mammals and can stimulate oxidative stress in them (Abdallah et al., 2012; El-Demerdash, 2007; Fetoui et al., 2008; Fetoui et al., 2009).

In the present study, the influences of the LCT on the LFT, histopathology of gonads, and reproductive hormones of insecticide-selected frogs as compared to unselected were investigated. To fulfill the reader demand, the study also searches the effects of LCT on histopathological changes in the male (testis) and female (ovaries) gonads, reproductive hormones (Testosterone, Progesterone, and Estrogen), liver function test (ALT, AST, Bilirubin, and Alkaline Phosphatase) as well as complete blood count (HCT, HGB, PLT, RBCs, and WBCs) of frogs.

\section{Materials and Method}

\subsection{Rearing of Rana tigrina}

The healthy and uninjured frog species, Rana tigrina, were experimented in the current research, collected from a paddy field where LCT was extensively applied. Five frogs were taken from those paddy fields where no insecticides were used and selected as a control group. Twenty frogs were taken for the research work and were kept in separate glass aquariums having 50 liters capacity filled with 20 liters water (Ruthsatz et al., 2020) and suitable environmental conditions were provided with respect to the rules of the INS laboratory of Zoology Researchers. Five frogs were kept in each aquarium to acclimatize them for 72 hours, granted with typical food (arthropods, insects), and were adjusted to the laboratory with careful surroundings for 1 week. The water of the aquarium was changed daily to keep the aquariums clean, less toxic, disease-free, and reduced turbidity. No external oxygen supply was provided to them. Frogs were bathed after three days with $1 \% \mathrm{NaCl}$ solution to avoid any fungal attack. After 1 week, twenty frogs were randomly taken and divided into 4 groups.

\subsection{Application of Insecticide}

Low, medium, and high doses of Lambda-Cyhalothrin (E. Merck Company, D-6100 Darmstand, F. R. Germany) 0.008, $0.010,0.012 \mathrm{mg} / \mathrm{L}$ were added with a one-day interval in the aquarium, labeled as, A, B, and C respectively, whereas control was not given to any dose.

\subsection{Hematological Assay}

One frog from each experimental group was selected randomly; pithed and excised after 7 days. Total $3 \mathrm{ml}$ of blood was collected via syringe from every individual and pour into EDTA-Gel Tubes $(1 \mathrm{ml}$ in each) to test the CBC, LFT, and reproductive hormone respectively. After that gonads were removed from frogs by making deep incisions on the ventral side and kept the gonads safely (Omonona and Emikpe, 2011). By using Sysmex automated hematology analyzer version KX-2, blood in EDTA tube was examined to test CBC. The estimation of LFT (aspartate transaminase AST, alanine transaminase ALT, bilirubin, and alkaline phosphatase), was determined by microlab 300 and reproductive hormones from the blood of males (testosterone) and females (estrogen and progesterone) frogs were analyzed by IMX Abbott using MEIA versions, which is $95.0 \%$ specific and $97.0 \%$ sensitive. 


\subsection{Gonad Assay}

Gonad after confiscation was washed with water and then drenched in $0.085 \%$ saline to clear them from any stain, grime, or blood. Tissues were cut into small pieces by way of a sterile dissection box into $3-4 \mathrm{~mm}$ thick pieces. After fixation, tissues were processed in a rotary microtome, later than stained slides were observed under a microscope (LABOMED FLR Lx 400; Jenoptic, Germany) for any histopathological change, and photomicrographs were taken under low (4x/0.10/0.17) magnification. The hematological study of Rana tigrina was investigated by applying one-way ANOVA using SPSS version 16.0 statistical software and statistical mean.

\subsection{Statistical Analysis}

The values of CBC including hematocrit (HCT), hemoglobin (HGB), platelets (PLT), red blood cells (RBCs), and white blood cells (WBCs); LFT consisting (ALT, AST, Bilirubin, and Alkaline Phosphatase) and reproductive hormones (Testosterone, Progesterone, and Estrogen) were evaluated by using one-way ANOVA using SPSS version 16.0.

\section{Results and Discussion}

In the present study, the effect of LCT on the Gonads, CBC, LFT, and reproductive hormones of frogs were investigated and statistical analysis was performed. LCT administration exerted adverse effects on the health of treated frogs. Acute and severe health complications like tremors, tiredness, dizziness, impaired movement, and low consumption of food have already been reported by (Fukuyama et al., 2009; Snipes et al., 2009).

\subsection{Histological Outcomes of Gonads of Control Group after Microtomy}

Morphological, histopathological, and hematological exploration of the control group signposted non-significant changes on the testis and ovaries, but they gradually lose their weight because of starvation. Toxicity of LCT exert toxic effects on behavior in experimental animals, frogs utilized less food and became inactive. Animals reduce food intake consequently decline in body growth. Reduction in body weight reveals many other health problems in animals and these might be reproductive disorders (Aly et al., 2009).

\subsection{Effect of LCT Compared with Control Group on Testis}

Testis showed pathological changes upon exposure to sub-lethal concentration of LCT but with time there were mild degenerative changes like mutilation and disruption in Sertoli cells, breaking of cyst walls and loosening of cells, thinning of smooth muscles' wall and deformation of cells of the epididymis, high disruption in seminiferous tubules, developing cells and sperms disintegration, nourishing cells rupture, breaking of cyst wall and loosening of cells, scattering of sperm bundles and mild degenerative changes, high pathological alterations like seminiferous tubules, developing cells, sperms and nourishing cells degeneration, necrosis in Sertoli cells and their total degeneration, scattering of sperm bundles, vacuolation of cytoplasm, shrunken tubules and reduction in sperm numbers and even there was exfoliation of sperms and the spermatids have degenerated, scattering of sperm bundles in some tubules and necrosis of Sertoli cells (Fig. $1 \& 2$ ).
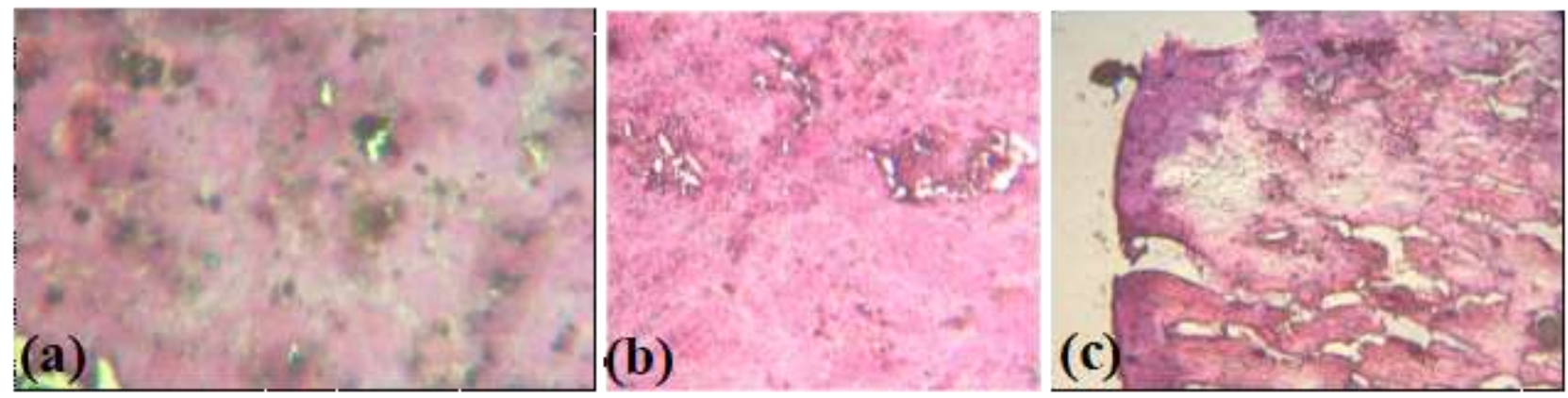

Fig. 1. Effects of LCT dosage on Sertoli testis cells; (a) control dosage, (b) low dosage, (c) high dosage. 

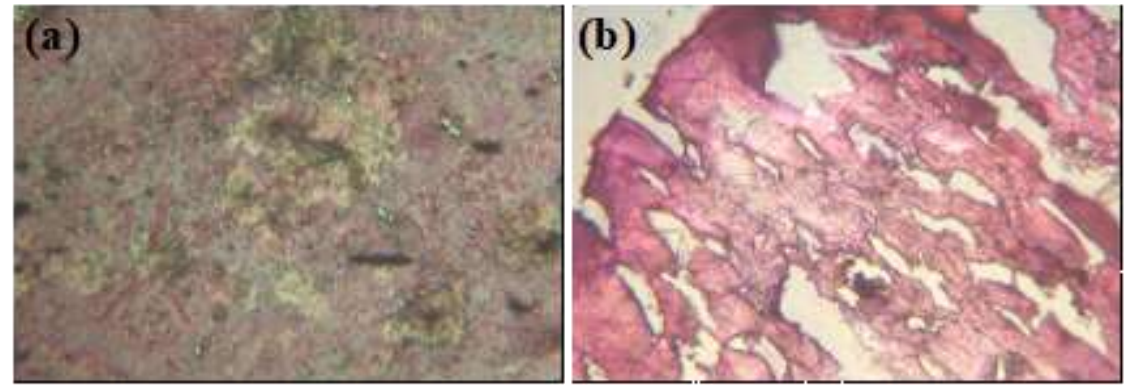

Fig. 2. Effects of LCT dosage on seminiferous testis tubules; (a) normal dosage, (b) medium dosage.

\subsection{Effect of LCT Compared with Control Group on Ovaries}

Histopathological symptoms of ovaries were like contraction of follicles and mild damage to nucleus, increase of atretic follicles, reduction in the number of oocytes, vacuolation in the stroma, deformation in granulosa cells and decreased maturity, highly disrupted and degenerative structures of ovaries, edema in the stroma and total degeneration, necrosis and decreased maturity (Fig. 3-5).

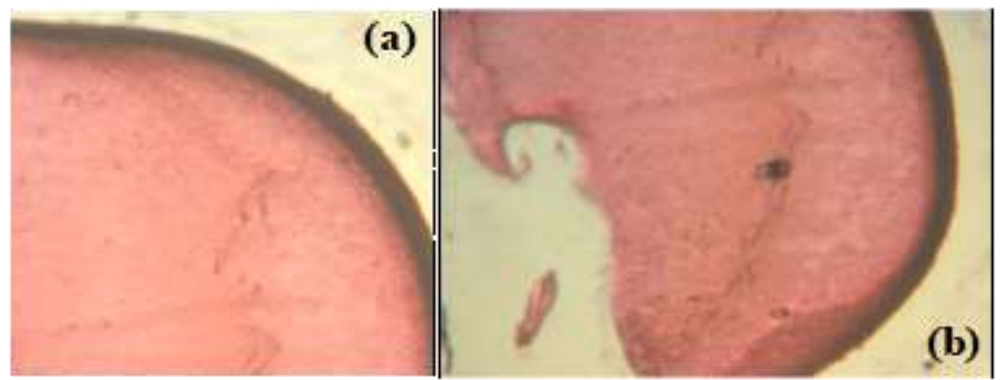

Fig. 3. Effects of LCT dosage on ovaries; (a) control dosage, (b) low dosage.

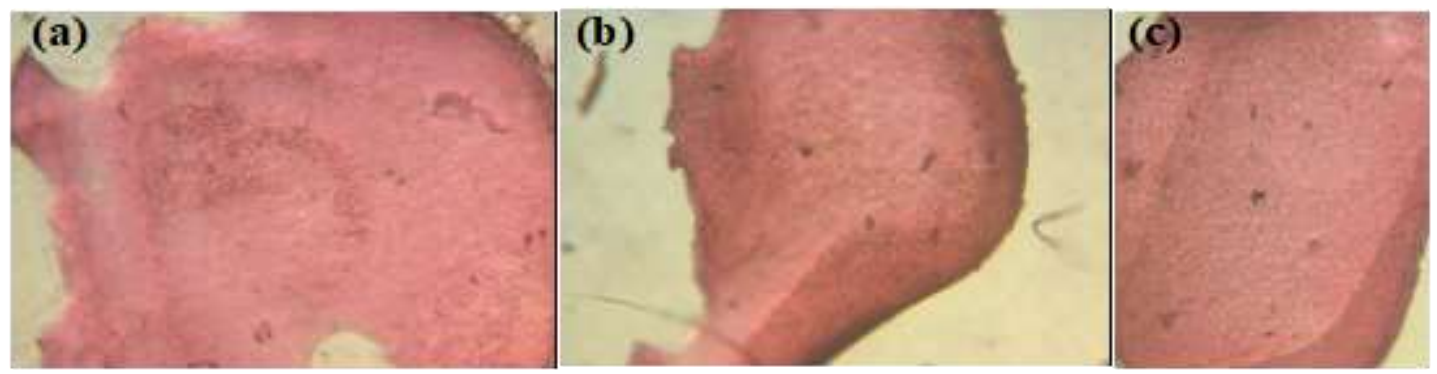

Fig. 4. Effects of LCT dosage on Granulosa's ovaries cells; (a) control dosage, (b) medium dosage, (c) high dosage. 


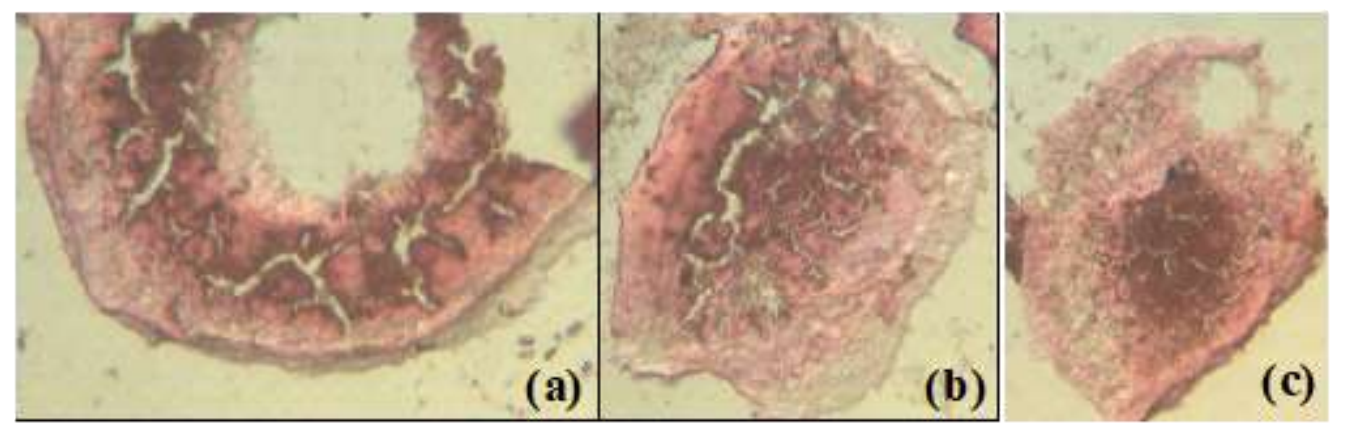

Fig. 5. Effects of LCT dosage on Follicle of ovaries; (a) low dosage, (b) medium dosage, (c) high dosage.

In addition to various clinical and neuro-toxicological effects, hazards of pyrethroids are alleged concerning reproductive noxiousness. The testicular and epididymal sperm counts and serum testosterone concentrations in pyrethroid treated animals decrease (Ahmad et al., 2012). The result of the reported studies reveals that exposure to pyrethroids creates anti-androgenic effects and disruption on reproductive organs and their secretions (Perry et al., 2007; Zhang et al., 2007).

The present investigation showed the injurious effects on testis like the breaking of cyst walls, mutilation, deformation in the epididymis, high disruption in seminiferous tubules, degeneration of cells and oocytes, discoloration, and edema in the stroma. Likewise, ovaries showed mild changes as well as a contraction in follicles, deformation, and disruption of granulosa's cells and oocytes. It was also observed an increase in testosterone and estrogen while a decrease in progesterone values in treated frogs.

\subsection{Statistical Analysis of Hematological Data}

The hematological study of Rana tigrina was investigated by applying one-way ANOVA using SPSS version 16.0 statistical software and statistical mean.

\subsection{Comparative Mean Values of Frog's Blood Treated with all Doses of LCT to Control Group}

The values of CBC (Complete Blood Count), LFT (Liver Function Test), and reproductive hormones of frogs after comparison between control and treated groups, low, medium, and high dose group of five weeks with respect to their mean values treatment with LCT were observed (Table 1).

\section{Table 1}

Values of CBC, LFT and reproductive hormones of frogs after comparison between control, low, medium and high dose group of five weeks with respect to their mean values treatment with LCT

\begin{tabular}{lcccc}
\hline \multirow{2}{*}{ Tests } & \multicolumn{3}{c}{ Doses } \\
\cline { 2 - 5 } & $\begin{array}{c}\text { Control } \\
\text { Group }\end{array}$ & $\begin{array}{c}\text { Low } \\
\mathbf{( 8 ~ p ) b})\end{array}$ & $\begin{array}{c}\text { Medium } \\
(\mathbf{1 0} \mathbf{~ p p b})\end{array}$ & $\begin{array}{c}\text { High } \\
(\mathbf{1 2} \mathbf{~ p p b})\end{array}$ \\
\hline$\underline{\mathbf{C B C}}$ & 90.58 & 179.38 & 217.58 & 178.46 \\
WBCs (TLC) & 0.072 & 0.062 & 0.088 & 0.058 \\
RBCs & 65.4 & 29.2 & 46.4 & 33.8 \\
PLTs & & & &
\end{tabular}




\begin{tabular}{|c|c|c|c|c|}
\hline HGB & 5.0 & 6.7 & 6.88 & 6.94 \\
\hline HCT (PCV) & 1.14 & 1.1 & 1.72 & 1.04 \\
\hline \multicolumn{5}{|l|}{$\underline{\text { LFT }}$} \\
\hline Bilirubin & 0.64 & 0.36 & 0.4 & 0.36 \\
\hline SGPT (ALT) & 35.6 & 34.8 & 42.6 & 37.8 \\
\hline SGOT (AST) & 133.2 & 147.2 & 141 & 203 \\
\hline $\begin{array}{c}\text { Alkaline } \\
\text { Phosphatase }\end{array}$ & 298.8 & 316.6 & 313.6 & 377.6 \\
\hline \multicolumn{5}{|c|}{ Reproductive Hormones } \\
\hline Testosterone & 3.84 & 0.288 & 3.236 & 5.05 \\
\hline Progesterone & 0.218 & 0.362 & 0.278 & 0.17 \\
\hline $\begin{array}{l}\text { Estrogen } \\
\text { (Estradiol) }\end{array}$ & 207 & 748.61 & 872.5 & 828.14 \\
\hline
\end{tabular}

Mean was applied as statistical analysis on CBC including RBCs, WBCs (Total Leucocytes Count; TLC), PLT (platelets), HCT (hematocrit) or PCV value, and HGB (hemoglobin). Variations of several hematological parameters and their relationships with natural or human-induced changes in the environment have been described in amphibians (Barni et al., 2007; Cabagna et al., 2005; Stansley and Roscoe, 1996). A decrease of mitotic erythrocytes was observed in two anuran species Scinax squalirostris and Leptodactylus mystacinus collected from rice fields (Barni et al., 2007). The results also demonstrated an increase in the values of HGB in the control group while variations showed in values of RBC's, WBC's, PLTs, and HCT in LCT selected animals.

In the previous study, an increase in AST and ALT in the liver which is significant at various levels after LCT and nuvan treatment in albino rats showed the toxicity of these two pesticides (Paliwal et al., 2009). The current results also exhibited an increase in the value of ALT and AST in the LCT treated frogs. Goseki et al. (1990) examined the enzymatic and immunological properties of alkaline phosphatase (ALP) in several tissues of bullfrog Rana catesbeiana. The inhibition and thermal inactivation studies showed that bullfrog ALP in the kidney, liver, and intestine had similar enzymatic properties. Also, mouse antiserum against bullfrog liver ALP cross-reacted with kidney and intestine enzymes as well as with liver enzyme. Similar to the previous study, present findings revealed that the liver enzyme (ALP) value was also increased with an increase in the concentration of LCT dose.

The reproduction rate was investigated for the first time, in the current study. The reproduction rate of frogs was also disturbed due to the application of LCT. When the values of estrogen (estradiol) of female frogs were analyzed through their mean values, a wide range of deviation was observed as there was an immense increase in hormonal values when the concentration of LCT was increased, whereas, progesterone (female hormone) also showed a variation among comparative values. Testosterone (male hormone) demonstrated a strange outcome when compared between groups but within dosage groups, there was a great increase in the mean values. Hence, when the effect of LCT was assessed, both sexes presented disquieting fluctuations in these hormones, which is clear evidence for the declining population of amphibians under the stress of different pesticides even used in minor quantities.

\subsection{ANOVA analysis}

\subsubsection{ANOVA on CBC}


When complete blood count (CBC) including hematocrit (HCT), hemoglobin (HGB), platelets (PLT), red blood cells (RBCs), and white blood cells (WBCs) values were evaluated, all showed a wide range of fluctuations illustrated that even a low dose of LCT also change the complete blood profile, shown in Table 2.

\section{Table 2}

Complete Blood Count (CBC) of R. tigrina showing negative effects of LCT after ANOVA

\begin{tabular}{|c|c|c|c|c|c|c|}
\hline \multirow[b]{2}{*}{$\mathrm{CBC}$} & \multicolumn{6}{|c|}{ ANOVA } \\
\hline & SOV & $\begin{array}{c}\text { Sum of } \\
\text { Squares }\end{array}$ & df & $\begin{array}{c}\text { Mean } \\
\text { Square }\end{array}$ & F-Test & $\begin{array}{c}\text { Sig. } \\
\text { (P-value) }\end{array}$ \\
\hline \multirow{3}{*}{ HCT } & $\begin{array}{c}\text { Between } \\
\text { Groups }\end{array}$ & 1.498 & 3 & 0.499 & \multirow{3}{*}{1.399} & \multirow{3}{*}{0.280} \\
\hline & $\begin{array}{l}\text { Within } \\
\text { Groups }\end{array}$ & 5.712 & 16 & 0.357 & & \\
\hline & Total & 7.210 & 19 & - & & \\
\hline \multirow{3}{*}{ HGB } & $\begin{array}{c}\text { Between } \\
\text { Groups }\end{array}$ & 12.852 & 3 & 4.284 & \multirow{3}{*}{1.140} & \multirow{3}{*}{0.363} \\
\hline & $\begin{array}{l}\text { Within } \\
\text { Groups }\end{array}$ & 60.120 & 16 & 3.758 & & \\
\hline & Total & 72.972 & 19 & - & & \\
\hline \multirow{3}{*}{ PLT } & $\begin{array}{c}\text { Between } \\
\text { Groups }\end{array}$ & 3932.200 & 3 & 1310.733 & \multirow{3}{*}{2.090} & \multirow{3}{*}{0.142} \\
\hline & $\begin{array}{l}\text { Within } \\
\text { Groups }\end{array}$ & 10036.000 & 16 & 627.250 & & \\
\hline & Total & 13968.200 & 19 & - & & \\
\hline \multirow{3}{*}{$\mathbf{R B C}$} & $\begin{array}{c}\text { Between } \\
\text { Groups }\end{array}$ & 0.003 & 3 & 0.001 & \multirow{3}{*}{1.359} & \multirow{3}{*}{0.291} \\
\hline & $\begin{array}{l}\text { Within } \\
\text { Groups }\end{array}$ & 0.011 & 16 & 0.001 & & \\
\hline & Total & 0.013 & 19 & - & & \\
\hline \multirow{3}{*}{ WBC } & $\begin{array}{c}\text { Between } \\
\text { Groups }\end{array}$ & 43409.744 & 3 & 14469.915 & \multirow{3}{*}{1.962} & \multirow{3}{*}{0.160} \\
\hline & $\begin{array}{l}\text { Within } \\
\text { Groups }\end{array}$ & 117977.116 & 16 & 7373.570 & & \\
\hline & Total & 161386.860 & 19 & - & & \\
\hline
\end{tabular}

The significant value for all studied parameters of $\mathrm{CBC}$ is (P-value $>0.05)$, which castoffs the Alternative Hypothesis $\left(\mathrm{H}_{1}\right)$. This sanction the average response (Null Hypothesis, $\mathrm{H}_{\mathrm{o}}$ ) of all applied doses $(8 \mathrm{ppb}, 10 \mathrm{ppb}$, and $12 \mathrm{ppb})$ with respect to all studied parameters of $\mathrm{CBC}$ is the same

\subsubsection{ANOVA on LFT}


When liver function test (LFT) including alkaline phosphatase, bilirubin, alanine transaminase (ALT), and aspartate transaminase (AST) values were evaluated, all values showed a wide range of fluctuations showed a high range of fluctuation at all doses of LCT, shown in Table 3.

\section{Table 3}

Liver function test viewing negative effects of LCT after ANOVA

\begin{tabular}{|c|c|c|c|c|c|c|}
\hline \multirow{2}{*}{ LFT } & \multicolumn{6}{|c|}{ ANOVA } \\
\hline & SOV & $\begin{array}{l}\text { Sum of } \\
\text { Squares }\end{array}$ & df & $\begin{array}{c}\text { Mean } \\
\text { Square }\end{array}$ & F-Test & $\begin{array}{c}\text { Sig. } \\
\text { (P-value) }\end{array}$ \\
\hline \multirow{3}{*}{$\begin{array}{c}\text { Alkaline } \\
\text { Phosphatase }\end{array}$} & $\begin{array}{c}\text { Between } \\
\text { Groups }\end{array}$ & 18214.150 & 3 & 6071.383 & \multirow{3}{*}{0.268} & \multirow{3}{*}{0.847} \\
\hline & $\begin{array}{l}\text { Within } \\
\text { Groups }\end{array}$ & 362368.400 & 16 & 22648.025 & & \\
\hline & Total & 380582.550 & 19 & & & \\
\hline \multirow{3}{*}{ Bilirubin } & $\begin{array}{c}\text { Between } \\
\text { Groups }\end{array}$ & 0.272 & 3 & 0.091 & \multirow{3}{*}{1.695} & \multirow{3}{*}{0.208} \\
\hline & $\begin{array}{l}\text { Within } \\
\text { Groups }\end{array}$ & 0.856 & 16 & 0.054 & & \\
\hline & Total & 1.128 & 19 & - & & \\
\hline \multirow{3}{*}{$\begin{array}{l}\text { SGOT } \\
\text { (AST) }\end{array}$} & $\begin{array}{c}\text { Between } \\
\text { Groups }\end{array}$ & 15156.200 & 3 & 5052.067 & \multirow{3}{*}{0.288} & \multirow{3}{*}{0.834} \\
\hline & $\begin{array}{l}\text { Within } \\
\text { Groups }\end{array}$ & 280847.600 & 16 & 17552.975 & & \\
\hline & Total & 296003.800 & 19 & & & \\
\hline \multirow{3}{*}{$\begin{array}{l}\text { SGPT } \\
(\text { ALT) }\end{array}$} & $\begin{array}{c}\text { Between } \\
\text { Groups }\end{array}$ & 184.200 & 3 & 61.400 & \multirow{3}{*}{0.139} & \multirow{3}{*}{0.935} \\
\hline & $\begin{array}{l}\text { Within } \\
\text { Groups }\end{array}$ & 7088.000 & 16 & 443.000 & & \\
\hline & Total & 7272.200 & 19 & & & \\
\hline
\end{tabular}

The significant value for all studied parameters of LFT is (P-value > 0.05), which rejects the Alternative Hypothesis $\left(\mathrm{H}_{1}\right)$. This confirms the average response (Null Hypothesis, $\mathrm{H}_{\mathrm{o}}$ ) of all applied doses (8 ppb, $10 \mathrm{ppb}$, and $\left.12 \mathrm{ppb}\right)$ with respect to all studied parameters of LFT is the same.

\subsubsection{ANOVA on Reproductive Hormones}

The fecundity of frogs is also badly affected due to the spraying of LCT on rice fields. Reproductive hormones of females (estrogen and progesterone) and males (testosterone) were assessed to check the effect of LCT. It demonstrated that populations of frogs might be at risk as there is a substantial change in the values of reproductive hormones than normal in both sexes (Table 4). 


\section{Table 4}

Reproductive hormones, estrogen and progesterone in female and testosterone in male presenting effects of LCT after ANOVA

\begin{tabular}{|c|c|c|c|c|c|c|}
\hline \multirow{2}{*}{$\begin{array}{l}\text { Reproductive } \\
\text { Hormones }\end{array}$} & \multicolumn{6}{|c|}{ ANOVA } \\
\hline & SOV & $\begin{array}{l}\text { Sum of } \\
\text { Squares }\end{array}$ & df & $\begin{array}{c}\text { Mean } \\
\text { Square }\end{array}$ & F-Test & $\begin{array}{c}\text { Sig. } \\
\text { (P-value) }\end{array}$ \\
\hline \multirow{3}{*}{$\begin{array}{c}\text { Estrogen } \\
\text { (Estradiol) }\end{array}$} & $\begin{array}{c}\text { Between } \\
\text { Groups }\end{array}$ & 1432110.130 & 3 & 477370.043 & \multirow{3}{*}{0.955} & \multirow{3}{*}{0.438} \\
\hline & $\begin{array}{l}\text { Within } \\
\text { Groups }\end{array}$ & 8000546.834 & 16 & 500034.177 & & \\
\hline & Total & 9432656.964 & 19 & - & & \\
\hline \multirow{3}{*}{ Progesterone } & $\begin{array}{c}\text { Between } \\
\text { Groups }\end{array}$ & 0.103 & 3 & 0.034 & \multirow{3}{*}{0.259} & \multirow{3}{*}{0.854} \\
\hline & $\begin{array}{l}\text { Within } \\
\text { Groups }\end{array}$ & 2.117 & 16 & 0.132 & & \\
\hline & Total & 2.219 & 19 & - & & \\
\hline \multirow{3}{*}{ Testosterone } & $\begin{array}{c}\text { Between } \\
\text { Groups }\end{array}$ & 63.082 & 3 & 21.027 & \multirow{3}{*}{0.834} & \multirow{3}{*}{0.494} \\
\hline & $\begin{array}{l}\text { Within } \\
\text { Groups }\end{array}$ & 403.244 & 16 & 25.203 & & \\
\hline & Total & 466.326 & 19 & - & & \\
\hline
\end{tabular}

The significant value for all studied parameters of reproductive hormones is (P-value $>0.05)$, which rejects the Alternative Hypothesis $\left(\mathrm{H}_{1}\right)$. This confirms the average response (Null Hypothesis, $\left.\mathrm{H}_{\mathrm{o}}\right)$ of all applied doses $(8 \mathrm{ppb}, 10 \mathrm{ppb}$, and $12 \mathrm{ppb}$ ) with respect to all studied parameters of reproductive hormones is the same.

The strong association between declines and upwind pesticide use points to the urgent need for additional research on the role of pesticides in amphibian declines. Field studies are needed to assess the types and amount of wind-borne pesticide exposure for declining species.

\section{Conclusions}

In conclusion, the present study describes the effects of Lambda-Cyhalothrin (LCT) on various histological and hematological features of frogs. Since LCT is frequently applied in rice fields in Pakistan, so complete analysis of the effect of LCT on amphibian's life is essential. Microtomy on gonads as well as statistical mean and ANOVA on blood profile of frogs was effectively performed to reveal the dosage effect of LCT. Lambda-cyhalothrin treatment showed the worst effects on frogs at the low (8 ppb), medium (10 ppb), and high (12 ppb) doses within five weeks. The damaging effects on male gonads (testis) proved the breaking of cyst walls, mutilation, deformation in the epididymis, high disruption in seminiferous tubules, degeneration of cells and oocytes, discoloration, and edema in the stroma. Likewise, female gonads (ovaries) showed mild changes as well as a contraction in follicles, deformation, and disruption of granulosa cells and oocytes. The hematological results after statistical analysis (P-value > 0.05) and mean values also proved the disrupting values of CBC, LFT, and reproductive hormones. All the above consequences confirmed the negative influence of LCT on male and female fertility of amphibians eventually reducing their population size. It is therefore imperative to understand the underlying 
mechanism of the toxicity of pesticides for amphibians to obtain a realistic estimate of the extent of their impact and to reconcile agricultural practice and amphibian conservation efforts.

\section{Conflicts of Interest}

The authors declare no conflict of interest.

\section{Acknowledgements}

The authors are thankful to Department of Zoology, University of Gujrat, Punjab, Pakistan for providing research facilities. This research did not receive any specific funding.

\section{References}

1. Abdallah, F.B., Fetoui, H., Fakhfakh, F. and Keskes, L., 2012. Caffeic acid and quercetin protect erythrocytes against the oxidative stress and the genotoxic effects of lambda-cyhalothrin in vitro. Human \& Experimental Toxicology, 31: 92-100.

2. Ahmad, L., Khan, A. and Khan, M.Z., 2012. Pyrethroid-Induced Reproductive Toxico-Pathology in Non-Target Species. Pakistan Veterinary Journal, 32: 1-9.

3. Alford, R.A. and Richards, S.J., 1999. Global amphibian declines: a problem in applied ecology. Annual Review of Ecology, Evolution, and Systematics, 30: 133-165.

4. Ali, S.F., Shieh, B.H., Alehaideb, Z., Khan, M., Louie, A., Fageh, N. and Law, F.C., 2011. A review on the effects of some selected pyrethroids and related agrochemicals on aquatic vertebrate biodiversity. Canadian Journal of Pure and Applied Sciences, 5: 1455-1464.

5. Aly, H.A., Domènech, Ò. and Abdel-Naim, A.B., 2009. Aroclor 1254 impairs spermatogenesis and induces oxidative stress in rat testicular mitochondria. Food and Chemical Toxicology, 47: 1733-1738.

6. Amweg, E.L., Weston, D.P. and Ureda, N.M., 2005. Use and toxicity of pyrethroid pesticides in the Central Valley, California, USA. Environmental Toxicology and Chemistry, 24: 966-972.

7. Barni, S., Boncompagni, E., Grosso, A., Bertone, V., Freitas, I., Fasola, M. and Fenoglio, C., 2007. Evaluation of Rana snk esculenta blood cell response to chemical stressors in the environment during the larval and adult phases. Aquatic Toxicology, 81: 45-54.

8. Bishop, C., 1992. The effects of pesticides on amphibians and the implications for determining the causes of decline in amphibian populations: Declines in Canadian amphibian populations designing a national monitoring strategy, (eds. Bishop, CA. and Pettit, KE.)

9. Canadian Wildlife Service, 76: 67-70.

10. Blaustein, A.R., Wake, D.B. and Sousa, W.P., 1994. Amphibian declines: judging stability, persistence, and susceptibility of populations to local and global extinctions. Conservation Biology, 8: 60-71.

11. Cabagna, M.C., Lajmanovich, R.C., Stringhini, G., Sanchez-Hernandez, J.C. and Peltzer, P.M., 2005. Hematological parameters of health status in the common toad Bufo arenarum in agroecosystems of Santa $\mathrm{Fe}$ Province, Argentina. Applied Herpetology, 2: 373.

12. Carey, C. and Bryant, C.J., 1995. Possible interrelations among environmental toxicants, amphibian development, and decline of amphibian populations. Environmental Health Perspectives, 103: 13-17.

13. Chen, J., Meng, T., Li, Y., Gao, K. and Qin, Z., 2018. Effects of triclosan on gonadal differentiation and development in the frog Pelophylax nigromaculatus. Journal of Environmental Sciences. 64: 157-165.

14. Davidson, C., Bradley Shaffer, H. and Jennings, M.R., 2001. Declines of the California red-legged frog: Climate, UV-B, habitat, and pesticides hypotheses. Ecological Applications, 11: 464-479.

15. Davidson, C., Shaffer, H.B. and Jennings, M.R., 2002. Spatial tests of the pesticide drift, habitat destruction, UVB, and climate-change hypotheses for California amphibian declines. Conservation Biology, 16: 1588-1601.

16. Ecobichon, D.J., 1991. Toxic effects of pesticides in casarett and doull's toxicology. Casarett and Doull's Toxicology: The Basic Science of Poisons,: 643-690.

17. El-Demerdash, F.M., 2007. Lambda-cyhalothrin-induced changes in oxidative stress biomarkers in rabbit erythrocytes and alleviation effect of some antioxidants. Toxicology in Vitro, 21: 392-397. 
18. Fetoui, H., Garoui, E.M., Makni-ayadi, F. and Zeghal, N., 2008. Oxidative stress induced by lambda-cyhalothrin (LTC) in rat erythrocytes and brain: attenuation by vitamin C. Environmental Toxicology and Pharmacology, 26: 225-231.

19. Fetoui, H., Garoui, E.M. and Zeghal, N., 2009. Lambda-cyhalothrin-induced biochemical and histopathological changes in the liver of rats: ameliorative effect of ascorbic acid. Experimental and Toxicologic Pathology, 61: 189196.

20. Fishel, F.M., 2005. Pesticide toxicity profile: synthetic pyrethroid pesticides. This document is PI-54, one of a Series of the Agronomy Department, Florida Cooperative Extension Service, Institute of Food and Agricultural Sciences, University of Florida: 1-54.

21. Fisher, R.N. and Shaffer, H.B., 1996. The decline of amphibians in California's Great Central Valley. Conservation. biology, 10: 1387-1397.

22. Fukuyama, T., Tajima, Y., Ueda, H., Hayashi, K., Shutoh, Y., Harada, T. and Kosaka, T., 2009. Allergic reaction induced by dermal and/or respiratory exposure to low-dose phenoxyacetic acid, organophosphorus, and carbamate pesticides. Toxicology, 261: 152-161.

23. Goseki, M., Oida, S. and Sasaki, S., 1990. Enzymatic and immunological properties of alkaline phosphatase of bullfrog. Journal of Experimental Zoology, 254: 1-5.

24. Grant, E.H.C., Muths, E., Schmidt, B.R. and Petrovan, S.O., 2019. Amphibian conservation in the Anthropocene. Biological Conservation. 236.

25. Greulich, K. and Pflugmacher, S., 2003. Differences in susceptibility of various life stages of amphibians to pesticide exposure. Aquatic Toxicology, 65: 329-336.

26. He, L.-M., Troiano, J., Wang, A. and Goh, K., 2008. Environmental chemistry, ecotoxicity, and fate of lambdacyhalothrin, Reviews of environmental contamination and toxicology. Springer, pp. 71-91.

27. Kumari, K. and Sinha, R., 2009. Acetylcholinesterase activity in the plasma and brain of the frog, Rana tigrina and toad, Bufo melanostictus following the treatment with carbaryl \& methyl parathion. The Journal of VN Karazin Kharkiv National University. Series, 9: 117-120.

28. Lawrence, E. and Isioma, T., 2010. Acute toxic effects of Endosulfan and Diazinon pesticides on adult amphibians (Bufo regularis). Journal of Environmental Chemistry and Ecotoxicology, 2: 73-78.

29. Lenkowski, J.R., Sanchez-Bravo, G. and McLaughlin, K.A., 2010. Low concentrations of atrazine, glyphosate, 2, 4-dichlorophenoxyacetic acid, and triadimefon exposures have diverse effects on Xenopus laevis organ morphogenesis. Journal of Environmental Sciences. 22: 1305-1308.

30. Li, L., Wang, W., Lv, Q., Ben, Y. and Li, X., 2014. Bioavailability and tissue distribution of Dechloranes in wild frogs (Rana limnocharis) from an e-waste recycling area in Southeast China. Journal of Environmental Sciences 26: 636-642.

31. Lu, Z., Gan, J., Cui, X., Delgado-Moreno, L. and Lin, K., 2019. Understanding the bioavailability of pyrethroids in the aquatic environment using chemical approaches. Environment international. 129: 194-207.

32. Majewski, M.S. and Capel, P.D., 1996. Pesticides in the atmosphere: distribution, trends, and governing factors. CRC Press.

33. Omonona, A. and Emikpe, B., 2011. Clinicopathological features associated with acute toxicity of lambdacyhalothrin pesticide in adult toads (Buffo Perreti). Advances in Environmental Biology 5: 808-814.

34. Paliwal, A., Gurjar, R. and Sharma, H., 2009. Analysis of liver enzymes in albino rat under stress of $\lambda$-cyhalothrin and nuvan toxicity. Biology and Medicine, 1: 70-73.

35. Pechmann, J.H., Scott, D.E., Semlitsch, R.D., Caldwell, J.P., Vitt, L.J. and Gibbons, J.W., 1991. Declining amphibian populations: the problem of separating human impacts from natural fluctuations. Science, 253: 892-895.

36. Pechmann, J.H. and Wilbur, H.M., 1994. Putting declining amphibian populations in perspective: natural fluctuations and human impacts. Herpetologica, 50: 65-84.

37. Perry, M.J., Venners, S.A., Barr, D.B. and Xu, X., 2007. Environmental pyrethroid and organophosphorus insecticide exposures and sperm concentration. Reproductive Toxicology, 23: 113-118.

38. Relyea, R.A., 2005. The impact of insecticides and herbicides on the biodiversity and productivity of aquatic communities. Ecological Applications, 15: 618-627.

39. Ruigt, G.S. and van den Bercken, J., 1986. Action of pyrethroids on a nerve-muscle preparation of the clawed frog, Xenopus laevis. Pesticide Biochemistry and Physiology, 25: 176-187. 
40. Ruthsatz, K., Dausmann, K.H., Reinhardt, S., Robinson, T., Sabatino, N.M., Peck, M.A. and Glos, J., 2020. Postmetamorphic carry-over effects of altered thyroid hormone level and developmental temperature: physiological plasticity and body condition at two life stages in Rana temporaria. Journal of Comparative Physiology. 190: 1-19.

41. Snipes, S.A., Thompson, B., O'Connor, K., Shell-Duncan, B., King, D., Herrera, A.P. and Navarro, B., 2009. "Pesticides protect the fruit, but not the people": using community-based ethnography to understand farmworker pesticide-exposure risks. American Journal of Public Health, 99: S616-S621.

42. Stansley, W. and Roscoe, D., 1996. The uptake and effects of lead in small mammals and frogs at a trap and skeet range. Archives of Environmental Contamination and Toxicology, 30: 220-226.

43. Van Den Bercken, J., 1977. The action of allethrin on the peripheral nervous system of the frog. Pestic. Sci., 8: 692699.

44. Vijverberg, H.P., van der Zalm, J.M. and van den Bercken, J., 1982. Similar mode of action of pyrethroids and DDT on sodium channel gating in myelinated nerves. Nature, 295: 601-603.

45. Wake, D.B., 1998. Action on amphibians. Trends in Ecology \& Evolution, 13: 379-380.

46. Zhang, S.-Y., Ito, Y., Yamanoshita, O., Yanagiba, Y., Kobayashi, M., Taya, K., Li, C., Okamura, A., Miyata, M. and Ueyama, J., 2007. Permethrin may disrupt testosterone biosynthesis via mitochondrial membrane damage of Leydig cells in adult male mouse. Endocrinology, 148: 3941-3949. 